\title{
COMPOSITION AND QUALITY OF FRESH COW MILK OFFERED FOR SALE IN PARTS OF PLATEAU STATE OF NIGERIA.
}

\author{
J.A. IBEAWUCHI AND D.M. DALYOP \\ Department of Animal Production, University of Agriculture, Makurdi, Nigeria. \\ Received 1 July, 1994; Acceoted 3 May, 1995
}

\section{ABSTRACT}

T he gross composition and quality of fresh cow milk purchased from Fulani milk vendors in three locations of Plateau State were investigated. Milk quality was assessed by the methylene blue reduction test while bacterial contamination was by the agar plate count and the direct microscopic count. The mean contents of total solids, butterfat, protein and ash of a total of 100 samples from Barkin Ladi, Jos and Bukuru markets were 12.45, 4.77, 3.90, $0.92 ; 12.85,4.50,3.68,0.93$; and $12.41,5.26,3.72$, $0.91 \%$ respectively. The proximate constituents did not differ significantly between locations. The methylene blue test indicated that only $23.5 \%$ of the sample were of good quality while 41.2 and $35.3 \%$ were rated fair and poor respectively. No sample merited excellent rating. The agar plate count showed a range of $1.97 \times 10^{6}$ for Bukuru to $2.54 \times 10^{6} \mathrm{cells} / \mathrm{ml}$ for Jos market. The direct microscopic count showed the highest mean bacteria value for Barkin Ladi samples. The high bacterial counts as observed were probably indicative of poor milking hygiene and handling. It is suggested that such milk should be properly pasteurized before consumption and delivered/marketed early at source to reduce the time for microbial multiplication.

Key Words: fresh cow milk. Composition, quality.

\section{INTRODUCTION}

In Nigeria, the indigenous cattle population estimated at about 13 million (Kaufmann et al., 1990), has been the major source of domestic milk supply. Milk supply from other animals such as sheep, goats and camels is negligible. The dairy industry still remains rural and traditional with the Fulani pastoralists controlling about $95 \%$ of the national herd (F.A.O., 1980). The annual collectable milk from the national herd is approximately 550 , 000 tonnes (Anon, 1990). Milking is usually done each morning and after the bousehold and calf requirements are met, the excess enters the traditional market as fresh or sour milk, cheese, ghee and butter for human consumption. Milk is delivered to the market mostly in covered calabashes by the Fulani women. The preference for calabash is due to its insulating guality.

As a result of the present decline in foreign exchange reserve earnings, dairy imports especially from the European Economic Community (EEC) have become very expensive to the extent that only few Nigerians can afford it. This situation led to a major shift in consumption from imported dairy products to local sources by a greater number of people especially in areas where these products are available. However, the main objection to the consumption of these locally available dairy products lies with the poor state of sanitation associated with the milking and handling processes. In this country, dairying is a family business operated at subsistence level without any regard to quality control. Milk, being a perishable commodity, demands a strict hygienic control. The lactating cows are usually not vaccinated against certain diseases under the traditional management systems. Eka and Ohaba (1977) have shown that 'nono', a fermented milk sold by Fulani milk vendors was highly contaminated with microorganisms. Another worker (Umoh, 1989) reported that about 99\% of 'fura-da-nono', a cereal food made from fermented milk, were contaminated with Staphylococci. The present study was therefore aimed at evaluating the composition and quality of cow milk marketed in three locations in Plateau State. 


\section{MATERIALS AND METHODS}

Milk samples used in the study were from Bunaji (White Fulani) cattle. The management system was mostly extensive as practised by the Fulani pastoralists. The animals were taken out for grazing on natural pasture early in the morning and herded to their holding pens in the evening. The sick ones and calves that were too weak to graze were left behind in the house. The calves were allowed to run with the dams for milk, except in the evening when they were confined in separate areas. Milking was done by hand each morning before grazing by Fulani women who delivered the excess milk to the market either as fresh or locally preserved forms. Generally, the animals received no supplementary feeding besides grazing and were usually not vaccinated against diseases. They were rarely dewormed or sprayed against ectoparasites.

\section{Milking Sampling}

Milk samples were taken in the rainy season (19th - 21st July, 1992). A total of 100 fresh samples were obtained from different milk vendors in three locations of Jos Plateau. Thirty-four $200 \mathrm{ml}$ samples were each obtained from the Jos and Barkin Ladi markets whereas thirty-two came from Bukuru. All sampling was done within three days due to the few number of fresh milk vendors in these locations. The samples were collected in properly labelled sterile plastic bottles between 8.30 and 9.30 a.m. each day and stored immediately in ice-packed coolers before transferring to a deep freezer at $-5^{\circ} \mathrm{C}$. The samples were later transported frozen to the University of Agriculture, Makurdi, and stored in a deep freezer until required for analysis.

\section{Analytical Procedure}

The milk samples were analysed for total solids (TS), crude protein (CP), fat, solids-non-fat (SNF) and ash. Total solids was obtained by drying about $5.0 \mathrm{~g}$ sample to a constant weight at about $105^{\circ} \mathrm{C}$ for 24 hours. Fat was estimated by the Roese-Gottlieb method as described by the A.O.A.C. (1980) procedure. Ash content was obtained by drying and ashing a weighed milk sample (10 $\mathrm{ml)}$ to a constant weight at $550^{\circ} \mathrm{C}$ for 48 hours. Milk protein ( $\mathrm{N} \times 6.38$ ) was determined using the semi-micro Kjeldahl and Markham's distillation apparatus. The difference between TS and fat gives the SNF. The $\mathrm{pH}$ was determined by the use of a $\mathrm{pH}$ meter (WPA CD6).

The milk samples were assessed for bacteriological quality using the standard plate count, the Methylene blue reduction test (APHA, 1953) and the Direct Microscopic count. In the standard plate count, colonies of bacteria were counted after incubation of a diluted milk sample in a petri dish containing a standard agar for 48 hours at $37^{\circ} \mathrm{C}$. One ml of diluted solution of methylene blue was added to $10 \mathrm{ml}$ of milk in a test tube and set in an incubator at $37.6^{\circ} \mathrm{C}$ and examined at intervals for colour change. In the direct microscopic count, $0.01 \mathrm{ml}$ of the sample was spread uniformly over a ruled area of $1 \mathrm{~cm}^{2}$ on a glass slide. This was examined under oil immersion objective previously calibrated to determine the area of the field.

\section{RESULTS AND DISCUSSION}

The mean values (\%) of TS, CP, fat, SNF, ash and $\mathrm{pH}$ of milk samples from the three locations (Barkin Ladi, Jos and Bukuru) are summarised in Table I. Analysis of variance showed that the TS, fat, CP, SNF and ash percentages as well as the $\mathrm{pH}$ of the samples did not differ significantly $(p>0.05)$ between the sources. The mean value of TS for Barkin Ladi, Jos and Bukuru markets were $12.45 \pm 1.3$, $12.85 \pm 1.7$ and $12.14 \pm 1.2 \%$ respectively. Comparable TS values have been reported from cows reared in Jos Plateau (Ibeawuchi, 1985, 1987; Ibeawuchi and Umoh, 1990). The butterfat values varied from $4.77 \%$ for Barkin Ladi samples to $5.60 \%$ for those of Bukuru. The butterfat, CP and ash values were similar to those reported for Friesian cattle (Akinsoyinu, 1981) and Bunaji or Bunaji X Friesian or Friesian cattle (Ibeawuchi and Umoh, 1990). The small variation in protein 
TABLE 1: CHEMICAL COMPOSITION OF MILK SAMPLES TAKEN FROM THREE LOCATIONS

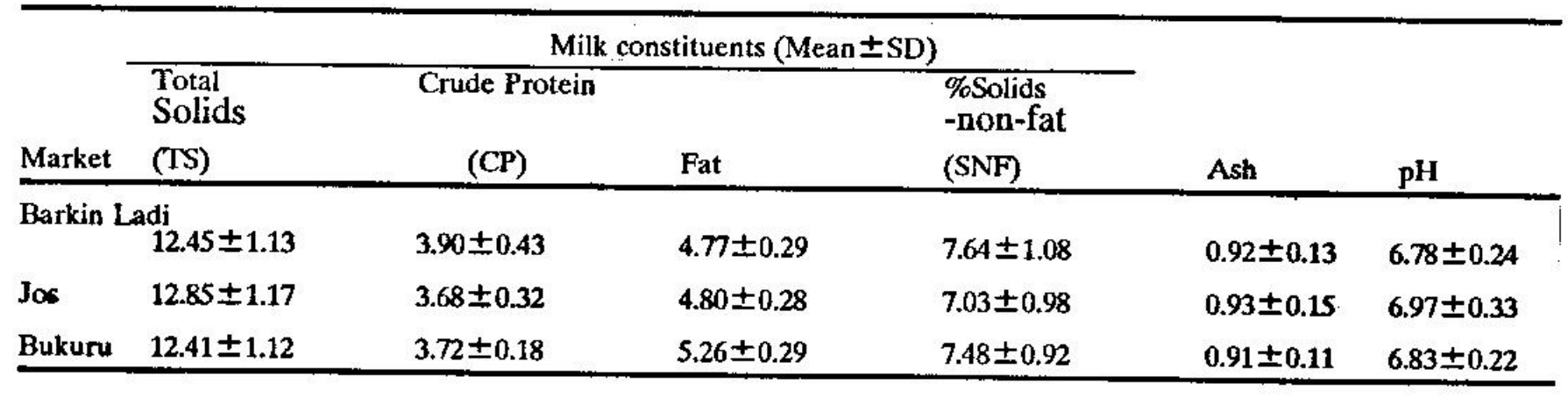

TABLE 2: METHYLENE BLUE REDUCTION TEST OF FRESH MILK SAMPLED FROM THREE LOCATIONS

\begin{tabular}{|c|c|c|c|c|c|c|c|}
\hline Market & $\mathbf{n}$ & Good & $\%$ & Fair & $\%$ & Poor & $\%$ \\
\hline Barkin Ladi & 34 & 8 & 23.5 & 14 & 41.2 & 12 & 35.3 \\
\hline Jo6 & 34 & 2 & 5.9 & 18 & 52.9 & 14 & 41.2 \\
\hline Bukuru & 32 & 8 & 25.0 & 12 & 37.5 & 12 & 37.5 \\
\hline
\end{tabular}

TABLE 3: BACTERIAL COUNT (MEAN) OF FRESH MILK SAMPLED FROM THREE LOCATIONS (MARKETS).

\begin{tabular}{|c|c|c|c|c|}
\hline Market & Agar Plate Count* & n & Direct Microscopic Count & $\mathbf{n}$ \\
\hline Barkin Ladi & $2.10 \times 10^{6}$ & 8 & $4.49 \times 10^{6}$ & 34 \\
\hline Jos & $2.54 \times 10^{6}$ & 8 & $3.93 \times 10^{6}$ & 34 \\
\hline Bukuru & $1.97 \times 10^{6}$ & 8 & $3.54 \times 10^{6}$ & 32 \\
\hline
\end{tabular}

content between the locations may have resulted from the metabolic activities of hacteria present in the milk. The absence of any major changes in the percentage fat content of milk is not expected as fat is the last major milk constituent to be used as substrate by microflora of milk. It has been reported (Seaman, 1963) that fat is usually not destroyed until the slower growing fungi have replaced bacteria, by which time there would be very little to identify the original medium as milk.

The results on quality tests of the samples are presented in Tables 2 and 3. Milk quality was classified on the basis of methylene reduction time. The present results showed that only $23.5,25.0$ and $5.9 \%$ of the Barkin Ladi, Bukuru and Jos market samples

Nigerian Journal of Animal Production 22(1) 1995 respectively were rated good whereas 35.3, 37.5 and $42.2 \%$ in that order were poor. The high mean values of bacteria counts (Table 3) could be responsible for the poor quality of the milk samples. Johns (1962) had reported that in the methylene blue dye test, the relationship between reduction time and viable counts was greatest with high count milk. The high bacteria counts obtained by the agar plate count and the direct microscopic count methods also confirmed the poor quality condition of the milk samples. The mean agar plate count compared favourably with the value of $2.48 \times 10^{6}$ obtained by Stadhourd (1982) in milk samples stored at $4^{0} \mathrm{C}$. Hammer (1957) observed a value of $3.26 \times 10^{6}$ for milk from clean source stored at $9.9^{\circ} \mathrm{C}$ for 72 hours, an indication that the high bacteria count was 


\section{J. A. IBEAWUCHI}

a reflection of poor hygiene. The present figures for the direct microscopic count is far greater than the figures obtained by the agar plate method which is in agreement with Lampert (1970).

The results of this study have shown that fresh cow milk sold by Fulani milk vendors in parts of Plateau State is highly contaminated with microorganisms. This could probably be due to poor milking hygiene as well as handling of harvested milk. It is advise $J$ that the interval between milking and delivery to market/selling be reduced as this would limit the time for microbial multiplication. It is also suggested that such milk should be pasteurized by boiling before consumption. The acceptable viable count for pasteurized milk that should be consumed should not exceed 30,000 organism/ml milk (APHA, 1953).

\section{ACKNOWLEDGEMENT}

We are grateful to MR. K. Akinpelu for technical assistance and also thank the Department of Food Science and Technology for assistance with microbiological analysis.

\section{REFERENCES}

AKINSOYINU, A.O. (1981). The composition of milk of the Friesian cattle imported into Nigeria. J. Sci. Food Agric. 32: 863 - 867.

ANON (1990). The History of Dairy Development in Nigeria. National Seminar on Dairy Production, Hill Station Hotel, Jos, 9 - 10th August.

A.O.A.C. (1980). Official Methods of Analysis of the Association of Official Analytical Chemists. 13th Ed., Washington, D.C.

APHA ( 1953). American Public Health Association. Standard Methods for the Examination of Dairy Products. 10th Ed. Washington, DC.

EKA, O.U. and OHABA, J.A. (1977). Microbiological examination of Fulani milk
AND

D. M. DALYOP

(nono) and butter (mansanu). Nig. J. Sci. 11: 113-122.

F.A.O. (1980). Trypanotolerant Livestock of West and Central Africa, F.A.O., Rome.

HAMMER, B. (1957). A review of the effect of $\mathrm{CO}_{2}$ on microbial growth and food quality. J. Food Sci. Tech. 48: 532 - 535.

IBEAWUCHI, J.A. (1985). A study on variation of some milk constituents of Friesian cows at Vom. Nig. J. Anim. Prod. Res. 5: 113 - 124.

IBEAWUCHI, J.A. (1987). Production characteristics of F1 Friesian $x$ Bunaji cattle in Vom. Nig. J. Anim. Prod. 14: 51 - 59.

IBEAWUCHI, J.A.and UMOH, B.I. (1990). Comparative studies of some milk constituents of White Fulani Cattle, Friesian and F1 Friesian $X$ White Fulani cattle in a tropical environment. Bull, Anim. Prod. Afr. 38: 253 - 257.

JOHNS, C.K. (1962). Milk Hygiene: Hygiene in Milk Production, Processing and Distribution. WHO Monograph Series. No. 48, Geneva.

KAUFMANN, R.R., ONUCHEYO, E. and EGEGE, S. (1990). Strategies for boosting milk production from traditional husbandry systems in Nigeria. Paper presented at the 2nd Nat. Dairy Seminar, Hill Station Hotel, Jos 9 - 10 August.

LAMPERT, L.M. (1970). Modem Dairy Products. Chemical Publ. Coy. Inc., New York.

SEAMAN, A. (1963). Bacteriology for Dairy Students. Cleaver-Hume Press Ltd., London.

STADHOURD, J. (1982). Cooling and thermization as a mean extend to keeping quality of raw milk. In: Proc. IDF Symp. On Bacteriological quality of milk. 34: 19-28.

UMOH, V.J. (1989). Contamination of Fura-da-nono by Staphylococci and growth of an enterotoxigenic Staphylococcus aureus in Fura - a cereal food. Zariya Veterinarian 4(2): 53 - 58. 